\title{
Ecotourism's Impact on Ethnic Groups and Households near Chitwan National Park, Nepal
}

\author{
Saroj Kandel ${ }^{1}$, Kazuhiro Harada ${ }^{1}$, Sudha Adhikari ${ }^{1} \&$ Nabin Kumar Dahal ${ }^{1}$ \\ ${ }^{1}$ Graduate School of Bioagricultural Sciences, Nagoya University, Nagoya, Japan \\ Correspondence: Kazuhiro Harada, Graduate School of Bioagricultural Sciences, Nagoya University, Furo-Cho, \\ Chikusa-Ku, Nagoya, 464-8601, Japan. E-mail: harada@agr.nagoya-u.ac.jp
}

Received: March 19, 2020

Accepted: May 15, $2020 \quad$ Online Published: May 30, 2020

doi:10.5539/jsd.v13n3p113

URL: https://doi.org/10.5539/jsd.v13n3p113

\begin{abstract}
The Chitwan National Park (CNP) is renowned as a premier attraction in Nepal. This study surveyed the ethnic communities and households living in the buffer zone (BZ) proximate to the CNP, where ecotourism has been strategically introduced to provide an alternative means of livelihood to the locals and to enhance biodiversity conservation. This study examined to what extent these households have economically benefited from local ecotourism activities as well as their perceptions of ecotourism. A structured questionnaire was used to collect data, surveying 145 Kumroj and Amaltari village households using a stratified random sampling technique. The findings indicated that similar ecotourism activities were taking place in both sites. We found that only certain households benefited directly, and that it was mostly the socioeconomically disadvantaged households that missed out on the livelihood opportunities provided by ecotourism. Further, it was revealed that the socio-economically disadvantaged locals still illegally extracted/sold forest products. However, such individuals also acknowledged that ecotourism has increased employment, social development, and forest conservation, and they desired to participate in ecotourism activities. This research can help policymakers better understand the gaps in their policies and restructure them to level the ecotourism playing field for all ethnic groups and economic levels (e.g., landowners versus non-landowners). This study recommends that policymakers rethink and reframe policies to protect the interests of communities living in the BZs of national parks, especially low-income households and/or locals who are disadvantaged because they do not have land or facilities to conduct ecotourism activities.
\end{abstract}

Keywords: buffer zone community forest, Chitwan National Park, ecotourism, ethnic groups, homestay

\section{Introduction}

Research on ecotourism in protected areas (PAs) worldwide shows that developing countries are promoting ecotourism as an effective tool for sustainable economic development and conservation strategies (Doan, 2000; K.C., 2016; Kiper, 2013; Scheyvens, 2000). The International Ecotourism Society (2015) advocates ecotourism as "responsible travel to natural areas that conserves the environment, sustains the well-being of the local people, and involves interpretation and education." According to Wight (1995), ecotourism must be different from traditional forms of tourism and it must be environmentally, socially, and economically balanced. Further, according to Wall (1997), ecotourism must be economically viable and beneficial to the local community.

In the context of Nepal, natural and cultural resources are unique tourist attractions. Of the world's 14 mountain ranges higher than $8,000 \mathrm{~m}, 8$ are in Nepal. The country's major attractions include mountaineering and hiking, as well as sights with cultural and religious heritage. According to a Ministry of Culture Tourism and Civil Aviation (2018) report, 940218 tourists arrived in Nepal in 2017, with 604091 visiting national parks and wildlife reserves. Considering the growing importance of the PA system globally, Nepal has established PA system with 12 national parks, one wildlife reserve, six conservation areas, one hunting reserve, and 13 buffer zones (BZs), covering 23.39\% of the country's land area (Department of National Parks and Wildlife Conservation, 2018). The establishment of Chitwan National Park (CNP) in 1973 marked the launch of Nepal's first biodiversity conservation program. Since then, Nepal has been focusing on and implementing several policies aimed at the conservation of PAs (Oli \& Dhakal, 2018). Initially, a top-down PA management model was used, where local people were not consulted before the conservation strategy was formulated. There were increasing conflicts and competition between the park authorities and local people for resources, as well as a lack of support and 
participation from the local communities (Thapa, 2012). This forced the government of Nepal to reconsider its strategy and formulate policies to attain sustainability. Therefore, Nepal amended its National Park and Wildlife Conservation Act of 1973 for the fourth time in 1993 and promulgated the concept of the BZ (Bhandari \& Jianhua, 2017).

The aforementioned Act granted 30-50\% of the park revenues for natural resources management and community development program in the BZ (Thing \& Poudel, 2017). This amendment is considered a milestone in the history of biodiversity conservation in Nepal (Dhakal \& Thapa, 2015). To manage the BZs efficiently, the BZ Management Regulation of 1996 was introduced as a key instrument to promote community forests (CFs) in the BZs (Thing \& Poudel, 2017). The BZCFs are a form of decentralized and community-based forest management activities with objectives such as addressing the local communities' needs and demands, reducing their dependency on PA resources - such as wood for fuel and non-timber forest products - and promoting ecotourism (Chitwan National Park, 2018b; Government of Nepal, 1999; Bhusal, 2014). This was seen as a vital policy transformation from the traditional management practice to a participatory approach in which BZ residents are acknowledged as major partners in biodiversity conservation (Sharma, 2012; Wells \& Sharma, 1998). This would entail suitable strategies to address the needs of local communities via active participation and engagement in community development activities (Pokharel et al., 2018). However, conflict persisted in some BZ villages because the use of natural resources, which were the community's only means of subsistence, had become illegal. Therefore, ecotourism has been strategically introduced around the peripheries of PAs as an alternative livelihood strategy for people living in and around these areas and to end the conflict between park staff and local people (Bhatt \& Dhakal, 2018).

According to Kiper (2013), ecotourism helps in community development by providing a sustainable, alternate source of livelihood to the local community. Similarly, Acharya and Halpenny (2013) wrote that community-based ecotourism in PAs has helped to strengthen the local communities' social and economic capacities. In Nepal, ecotourism has been growing consistently since the 1980s (Bhatt \& Dhakal, 2018). Initially, tourism in Nepal focused on mountaineering, but the government has since shifted its focus to promoting tourism via BZs and the protected areas. The primary intention in regard to creating protected areas was to preserve the landscapes; however, this initiative later evolved by adding the promotion of tourism as a second objective. Therefore, it is necessary for the country to strike a balance between ecotourism and environmental preservation (Bhusal, 2009). Ecotourism is not a new venture for Nepal, but it gained traction among tourists who wanted to experience unique culture, nature, and wildlife up close (Prabin, 2015). Therefore, as K.C. (2016) wrote, ecotourism is regarded as a crucial tool for conservation and community development.

Recently, research on the CNP from different ecotourism-related perspectives has been rapidly increasing due to its rich ecological value; furthermore, it is a world heritage site and is renowned as a prime tourism destination in Nepal (Bhusal, 2009). Some studies conducted in the CNP have attempted to cover various aspects of ecotourism. For instance, Bhusal (2009) focused on tourism activities conducted in the CNP and Thakuri and Nepal (2018) emphasized how homestays came into effect in the CNP's peripheral locations and reviewed their challenges. Homestays are very important for Nepal's ecotourism; during a homestay, the traveler pays to stay at a local's home to interact with the host family and experience their culture (Lynch, 2005). The majority of homestay activities occur in rural areas and are managed by local communities (Jamal et al., 2011).

In 2014, a study was conducted to examine the impact of tourism, but it only focused on the CNP's Tharu community (Lipton, 2014). However, the literature lacks an examination of the impact of ecotourism on various ethnic groups of different economic statuses. The term "ethnic group" can be used to describe a group of people who follow a certain belief system that may result from their customs, physical similarities, or both (Weber, 1978). To frame a policy that provides equal opportunity and benefits to everyone, one must consider the perceptions of all the ethnic groups residing within the CNP since they engage in different kinds of activities and belong to different economic classes. Therefore, this study covers all the ethnic groups residing in the CNP and reveals their perceptions about ecotourism, which can help policymakers understand the gaps in their policies and restructure them to balance the interests of all the ethnic groups. This study also reveals various factors that shaped the different perceptions of various ethnic groups toward ecotourism.

\section{Materials and Methods}

\subsection{Study Site}

The CNP, which is designated as Nepal's first national park, lies in Nepal's southern border with India (Dongol, 2013). In 1984, the United Nations Environmental, Scientific and Cultural Organization declared CNP a World Heritage Site because of the rich ecosystem and culture surrounding the park (Bhusal, 2009). The park is located 
in tropical and subtropical climatic zones and extends from the sea level to heights between 150 meters and 815 meters. The park has so far been found to be home to at least 68 species of mammals, more than 576 species of birds (including 22 of the world's rarest species), 39 species of reptiles, 120 species of amphibians and fish, and hundreds of species of butterflies and other insects or invertebrates (CNP, 2017). Notably, the park is renowned for protecting endangered species such as the one-horned rhinoceros (Rhinoceros unicornis), the Royal Bengal tiger (Panthera tigris tigris), and the Gharial crocodile (Gavialis gangeticus) (International Union for Conservation of Nature, 2018). According to CNP's 2017-18 annual report, CNP covers an area of $952.63 \mathrm{~km}^{2}$ and its BZ covers $729.37 \mathrm{~km}^{2}$ (CNP, 2018a). As per the provision of the $1996 \mathrm{BZ}$ management regulation, the forest area in a BZ area can be managed as a BZ community forest, BZ religious forest, BZ leasehold forest, and/or a private forest (CNP, 2018b). By the time the 2017-18 CNP annual report was prepared, 68 BZCFs had already been handed over to the local community for management and use. The total area of transferred BZCFs is 13418.85 hectares, benefiting 42886 households and 223555 users (CNP, 2018a). Due to population migration and growth, the current population is estimated to be growing drastically. CNP is known as not only one of the best destinations for wildlife-based safari tourism in the world but also the first safari tourism destination in South Asia. According to data from Nepal's National Park and Wildlife Conservation Department, during the fiscal year of 2015-2016, a total of 387383 foreign tourists visited Nepal's PAs. In terms of numbers, CNP is among the five most visited PAs that witnessed the visit of 87391 foreigners during the same year. Moreover, its ecotourism revenue accounts for the largest share of CNP and BZ area income (CNP, 2017).

The CNP and its BZ have been divided into four sectors: Kasara (Central), Sauraha (Eastern), Amaltari (Western), and Bagai-Madi (Southern) (CNP, 2016). To ensure greater comparability, we selected two ecotourism communities: the Kumroj and Amaltari villages, which are located in the eastern and western sectors of CNP adjacent to the Kumroj BZCF and Gundrahi Dhakaha BZCF, respectively (Figure 1).

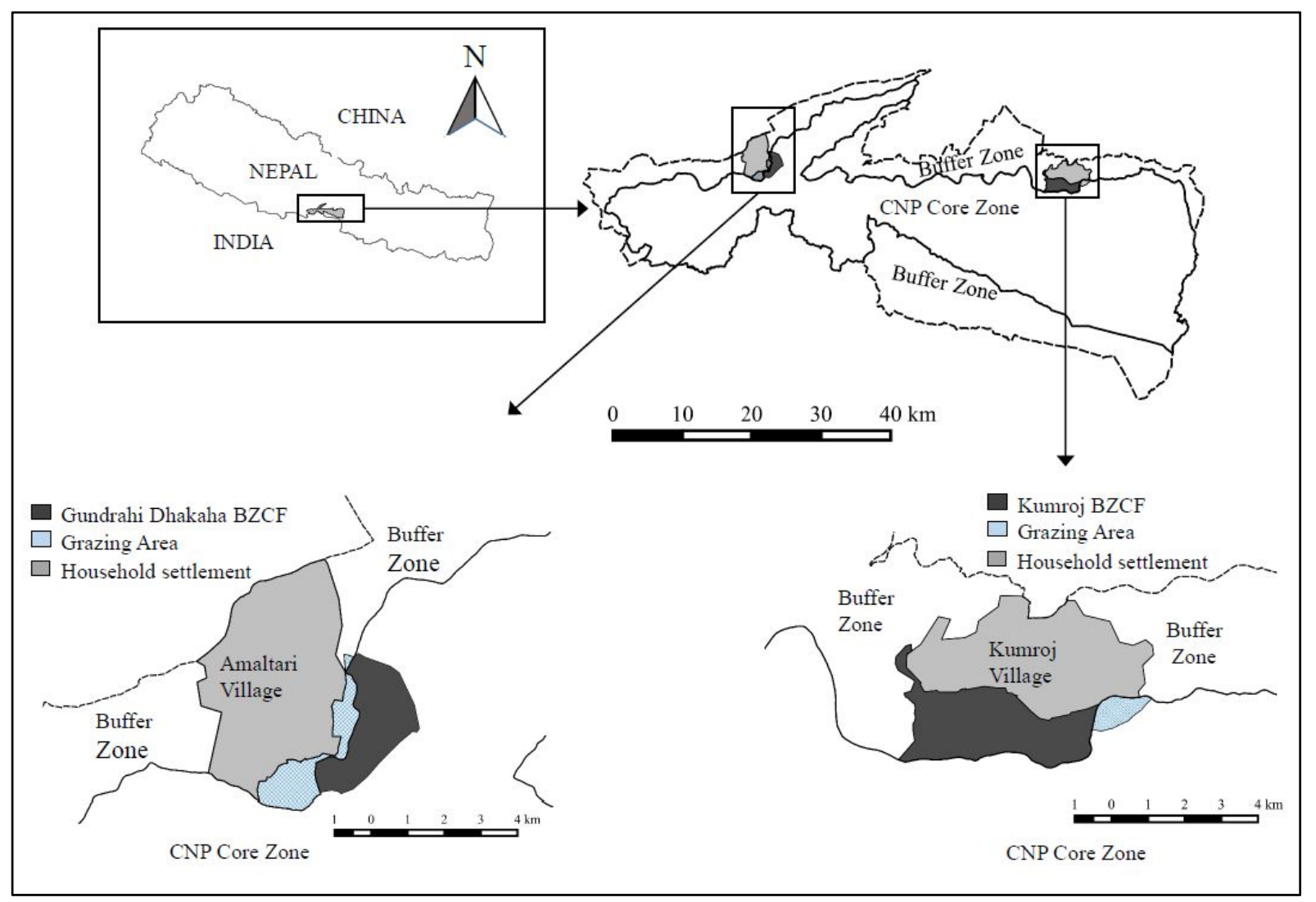

Figure 1. Map of Chitwan National Park that depicts the study areas

We also considered unique ethnic compositions, taking into account different income levels and social statuses, thus providing insights into the overall condition of various ethnicities in the village. Historically, inhabitants of the CNP BZ only comprise indigenous groups, such as the Botes, Darai, Kumal, Musahar, and Tharus, Several other ethnic groups (Hill migrants) migrated to the CNP BZ after successful eradication of malaria in the 
mid-1950s (Lamichhane et al., 2018; Lipton, 2014). Currently, the community includes a mixture of indigenous people and Hill migrants (Lamichhane et al., 2018). Although the local communities' livelihood primarily depends on agriculture and livestock husbandry (Kandel, Harada, Adhikari, Dahal, \& Dhakal, 2020), many new economic activities such as tourism and commercial farming are gaining popularity (Lamichhane et al., 2018).

\subsection{Study Description and Methods}

Fieldwork for this study was conducted in May/June 2018 and February 2020. The overall study methodology aimed at collecting a mix of qualitative and quantitative data. The qualitative data were used to supplement and explain the quantitative data. In this study, we used participant observation and key informant interviews to check the validity and reliability of answers given by respondents during structured interviews. According to the BZCFs forest users list of 2017, the selected Kumroj and Amaltari hamlets consisted of 181 and 290 households, respectively. The research area comprised four major ethnic groups with different economic statuses. Based on the surnames in the forest users' list received from the respective BZCF user committees (BZCFUCs), the respondents were categorized into four ethnic groups: 1) Brahman-Kshetri, 2) Tharu, 3) Janajati (Bote, Darai, Gurung, Tamang, and, Magar), and (4) Dalits (Damai, Musahar, and Sarki). Then, a stratified random sampling technique was implemented to select households of various ethnic groups from both hamlets. The size of an entire sample, n, was taken as approximately $30 \%$ of the total households, $\mathrm{N}$, from the selected hamlets. The survey shared a common framework across two hamlets. However, due to the small size of Dalit households in Kumroj, all willing residents were interviewed, yielding a 71\% sample size. In total, 145 face-to-face household interviews were conducted: 58 in Kumroj and 87 in Amaltari. (Table 1) summarizes the distribution of the household respondents in the selected villages.

Table 1. Total number of surveyed households in respective hamlets

\begin{tabular}{|c|c|c|c|c|}
\hline & \multicolumn{2}{|c|}{ Kumroj } & \multicolumn{2}{|c|}{ Amaltari } \\
\hline Ethnicities & $\begin{array}{l}\text { Hous eholds } \\
\text { based on } \\
\text { ethnicity }(\mathrm{N})\end{array}$ & $\begin{array}{c}\text { Sampled } \\
\text { HH (n) }\end{array}$ & $\begin{array}{l}\text { Hous eholds } \\
\text { based on } \\
\text { ethnicity }(\mathrm{N})\end{array}$ & $\begin{array}{c}\text { Sampled } \\
\text { HH (n) }\end{array}$ \\
\hline Brahman-Kshetri & 58 & $18(31.0 \%)$ & 46 & $14(30.0 \%)$ \\
\hline Tharu & 82 & $25(30.5 \%)$ & 143 & $43(30.0 \%)$ \\
\hline Janajati & 34 & $10(29.4 \%)$ & 64 & $19(30.0 \%)$ \\
\hline Dalits & 7 & $5 *(71.4 \%)$ & 37 & $11(30.0 \%)$ \\
\hline Total & 181 & $58(32.0 \%)$ & 290 & $87(30.0 \%)$ \\
\hline
\end{tabular}

Source: Records of respective buffer zone community forest user committee (BZCFUFs), (2017-2018)

Note: 1)* In the case of Kumroj, due to the small number of Dalit households (5), $71 \%$ households were interviewed.

2) HH indicates respondent's household

As there are many indigenous and minority ethnic people living in the research area, to overcome the language barrier, interpreters were used during interviews with respondents who did not understand Nepali or English. Household heads were interviewed based on their availability during the visits. When the heads were not available, we interviewed a senior member of the household who was at least 18 years of age. Each interview lasted 30-60 minutes.

The questionnaire had three sections. First, we aimed to understand the respondents' socio-economic statuses and inquired about their demographic characteristics, including gender, age, education level, ethnicity, landholding status, and if the household extracted natural resources (such as firewood and non-timber forest products) from the BZCF. Second, we asked about the economic activities the household members engaged in and their annual income. In the next step, we calculated the influence of various demographic characteristics such as ethnicities, along with their landholding status, in relation to the various economic activities that they engaged in. Finally, to examine residents' attitudes toward ecotourism in the BZCF, the questionnaire had six statements to which respondents were asked to respond with "Agree," "Disagree," or "Do Not Know." Analyses of quantitative data were made using Microsoft Excel 2010. 


\section{Results}

\subsection{Respondents' Household Characteristics}

Table 2 shows the household characteristics of the respondents. The gender ratio of the respondents was 6:4 in Kumroj village, whereas it was nearly equal in Amaltari village. The majority of respondents from both study areas were over 40 years old. In terms of education, a higher number of respondents had no formal education. The tertiary education level was higher in Amaltari than in Kumroj. In terms of ethnic distribution, the Tharu community was in majority followed by Brahman-Kshetri and Janjati. Dalits were the lowest in number in both study areas. Dalit households in Amaltari were higher than in Kumroj. Regarding landholding status, 22.8\% respondents did not have their own land and were settled in the BZCF encroachment areas wherein they illegally occupied the common lands without permission from the relevant authorities - therefore being classified as squatters (Robinson, 2004). In Amaltari, $82.8 \%$ of the respondents owned private land, whereas in the case of Kumroi, $69.0 \%$ of respondents were private landowners. A higher number of respondents from both villages owned livestock. The responses also showed that a higher number of people from both villages extract resources from the BZCF.

Table 2. Household and respondent characteristics

\begin{tabular}{|c|c|c|c|}
\hline Variable & Kumroj $(n=58)$ & Amaltari $(n=87)$ & Total $\mathbf{n}$ \\
\hline \multicolumn{4}{|l|}{ Gender } \\
\hline Male & $35(60.3 \%)$ & $42(48.3 \%)$ & $77(53.1 \%)$ \\
\hline Female & $23(39.7 \%)$ & $45(51.7 \%)$ & $68(46.9 \%)$ \\
\hline \multicolumn{4}{|l|}{ Age interval } \\
\hline $18-40$ & $14(24.1 \%)$ & $39(44.8 \%)$ & $53(36.6 \%)$ \\
\hline$>40$ & $44(75.9 \%)$ & $48(55.2 \%)$ & $92(63.4 \%)$ \\
\hline \multicolumn{4}{|l|}{ Education level } \\
\hline No Formal education & $34(58.6 \%)$ & $47(54.0 \%)$ & $81(55.9 \%)$ \\
\hline Primary & $12(20.7 \%)$ & $11(12.6 \%)$ & $23(15.9 \%)$ \\
\hline Secondary and Higher secondary & $12(20.7 \%)$ & $12(13.8 \%)$ & $24(16.5 \%)$ \\
\hline Tertiary & 0 & $17(19.6 \%)$ & $17(11.7 \%)$ \\
\hline \multicolumn{4}{|l|}{ Ethnicity } \\
\hline Brahman-Kshetri & $18(31.0 \%)$ & $14(16.1 \%)$ & $32(22.1 \%)$ \\
\hline Tharu & $25(43.1 \%)$ & $43(49.4 \%)$ & $68(46.9 \%)$ \\
\hline Janajati & $10(17.3 \%)$ & $19(21.9 \%)$ & $29(20.0 \%)$ \\
\hline Dalit & $5(8.6 \%)$ & $11(12.6 \%)$ & $16(11.0 \%)$ \\
\hline \multicolumn{4}{|l|}{ Land holding status } \\
\hline Landless (Squatters) & $18(31.0 \%)$ & $15(17.2 \%)$ & $33(22.8 \%)$ \\
\hline Private land & $40(69.0 \%)$ & $72(82.8 \%)$ & $112(77.2 \%)$ \\
\hline \multicolumn{4}{|l|}{ Livestocks } \\
\hline Yes & $51(87.9 \%)$ & $57(65.5 \%)$ & $108(74.5 \%)$ \\
\hline No & $7(12.1 \%)$ & $30(34.5 \%)$ & $37(25.5 \%)$ \\
\hline \multicolumn{4}{|l|}{ Extraction of natural resources } \\
\hline Yes & $40(69.0 \%)$ & $84(96.6 \%)$ & $124(85.5 \%)$ \\
\hline No & $18(31.0 \%)$ & $3(3.4 \%)$ & $21(14.5 \%)$ \\
\hline
\end{tabular}

Source: Field Survey, 2018

Note: 1) The figures in parentheses represent the percentage of respondents.

2) "n" indicates the size of an entire sample from each study site. 


\subsection{Ecotourism Activities in the Study Sites}

Both study areas began operating ecotourism activities inside the BZCF. Kumroj started its activities in 1996, which were initially limited to jungle walks and birdwatching. In 2010, Kumroj and Amaltari initiated mainstream activities such as jungle safaris, Jeep safaris, and homestays. Ecotourism activities inside the BZCFs are managed by each village's BZCFUC.

The results show that the Kumroj BZCFUC (Kumroj) has higher forest-based ecotourism profits in comparison to the Gundrahi Dhakaha BZCFUC (Amaltari). In fiscal year 2016-17, the Kumroj BZCFUC and Gundrahi Dhakaha BZCFUC earned NPR 5996713 and NPR 1120 326, respectively, from ecotourism (excluding homestays) inside the BZCFs (Figure 2). According to BZCF officials, revenue from ecotourism will further increase if the government or any organization support them in advertising.

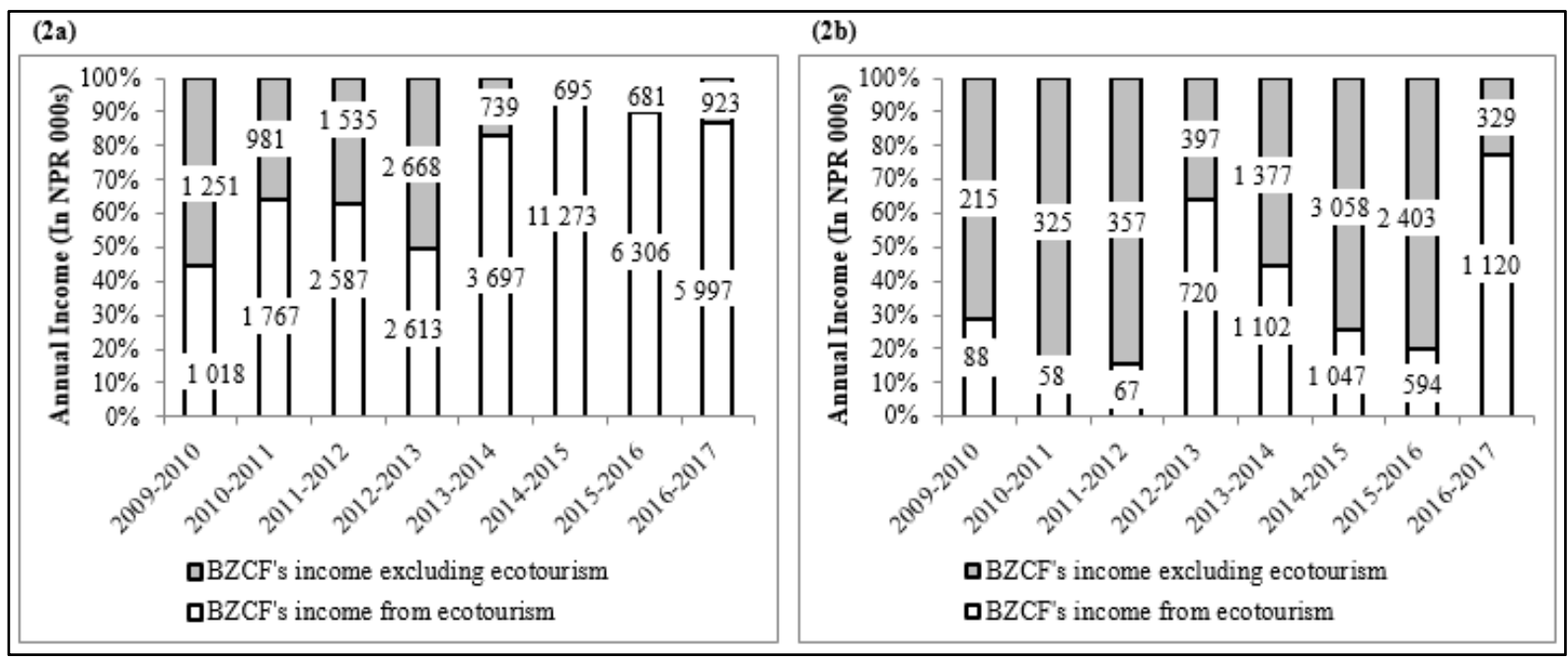

Figure 2. Annual revenues of the Kumroj buffer zone community forest user committee (BZCFUC) (2a) and Gundrahi Dhakaha BZCFUC (2b).

Source: The data of figure (2a) and (2b) were received from Kumroj BZCFUC and Gundrahi Dhakaha BZCFUC, respectively.

Note: (1) Buffer zone community forest (BZCF) income from ecotourism excludes homestay activities.

(2) Nepalese fiscal year is from 16 July to 15 July.

(3) As of 2019/5/29 1 NPR $=\$ 0.0090$.

According to the Kumroj and Amaltari homestay committees, they have been offering homestay facilities since December 26, 2013, and May 19, 2013, with five and twenty homestay facilities, respectively. A homestay program was started in the BZ villages with the help of governmental and non-governmental organizations. The homestay operations in villages, on the other hand, are managed by the homestay operating committee of the respective village. The task of homestay management and related responsibilities were handed over to homestay operators. These individuals must pay $10 \%$ of the income earned from the homestays to the homestay operating committee. As of fiscal year 2016/2017, nearly 11 and 24 homestay facilities were operating in Kumroj and Amaltari, respectively. The results showed that during the fiscal year of 2016/2017, 1119 domestic tourists and 60 foreigners stayed at homestays in Kumroj, while 13766 domestic tourists and 164 foreigners used the homestay facilities provided in Amaltari (Figure 3). During the same year, the homestay operating committees in Kumroj and Amaltari earned NPR 75000 and NPR 3900 884, respectively. 


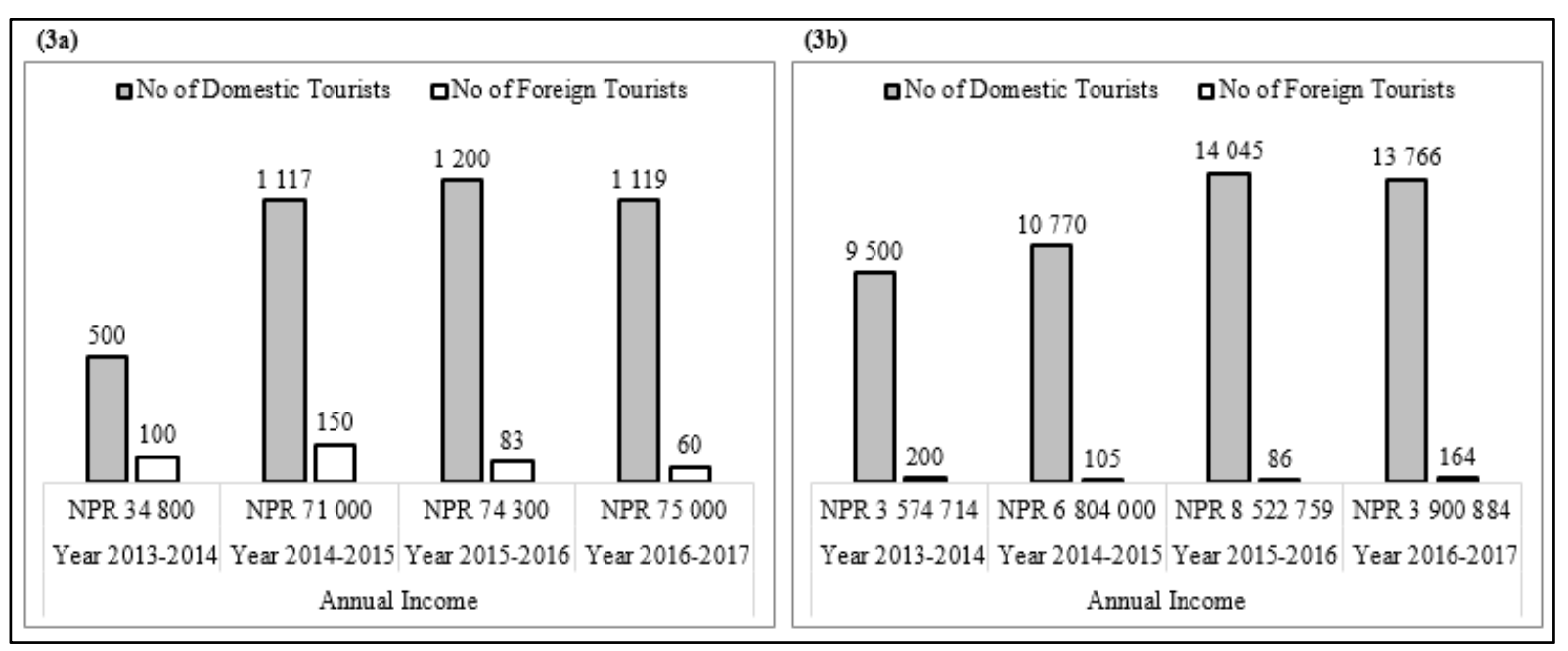

Figure 3. Revenue generated by the Kumroj (3a) and Amaltari (3b) homestay operating committees

Amaltari's homestay operating committee earned additional money from other activities such as cultural performances. In Amaltari, $10 \%$ of the revenue collected by the operating committee is mostly used to extend loans to people who are engaged in homestay activities. In addition, part of the revenue is invested in sustainable development, which covers road construction, economic upliftment of the local people, preserving the local culture, and education and health services. The Amaltari homestay operating committee spends $2 \%$ of its revenue on conservation, $2 \%$ on social development, $1 \%$ on health, $1 \%$ on education, and $4 \%$ on administration. Based on field observations, we found that the Kumroj homestays are in poor condition because they were not able to generate a significant amount of revenue. During an informal discussion, one of the members of the Kumroj homestay operating committee said that tourists preferred staying at the "Sauraha" tourist hub located nearby rather than choosing a homestay; this is the main reason for the poor performance of homestays in Kumroj.

In summary, Kumroj earns much more than Amaltari from ecotourism activities inside the BZCF, while Amaltari's revenue with regard to homestays exceeds that of Kumroj's significantly.

\subsection{Economic Activities of Respondents and Sources of Annual Income}

Table 3 presents the respondents' households' main sources of income. Two sources of income were identified: those related to ecotourism and those unrelated to it.

With regard to sources of income from ecotourism, the results indicate that the Amaltari respondents were more involved and earned higher income from ecotourism than those in Kumroj. A higher number of respondents from both study sites were involved in homestay facilities, rendering it the primary source of income for those involved in ecotourism activities.

In case of non-ecotourism sources of income, more respondents from Kumroj were involved in wage labor for their livelihood; in contrast, in the case of Amaltari, most respondents were involved in agricultural activities. However, the results show that in neither Kumroi nor Altamari did agricultural activities significantly contribute to the annual household income. Remittances were found to be the largest source of non-ecotourism related household income in both the study sites. The second predominant type of income came from trade businesses such as grocery shops, rice mills, and hardware shops. Meanwhile, livestock keeping and the sale of forest products, including products such as ferns, nettle, and fish, contributed the least. Notably, more respondents in Amaltari were involved in forest product trading than those in Kumroj. Finally, the results demonstrate that income from ecotourism comprised only $11.6 \%$ of the respondents' livelihoods, while $88.4 \%$ of that income came from other non-ecotourism activities. 
Table 3. Main sources of annual income in Nepalese rupees, 2017

\begin{tabular}{|c|c|c|c|c|c|c|c|c|}
\hline \multirow[t]{2}{*}{ Source of Income } & \multicolumn{2}{|c|}{$\begin{array}{l}\text { Kumroj village } \\
\quad n=58\end{array}$} & \multicolumn{2}{|c|}{$\begin{array}{l}\text { Amaltari village } \\
\quad \mathbf{n}=87\end{array}$} & \multirow[t]{2}{*}{ Total $n^{*}$} & \multirow[t]{2}{*}{$n *(\%)$} & \multirow[t]{2}{*}{ Total income } & \multirow[t]{2}{*}{$\begin{array}{l}\% \text { of Total } \\
\text { of incom e }\end{array}$} \\
\hline & $\mathrm{n}^{*}$ & $\begin{array}{c}\text { Total } \\
\text { Income }\end{array}$ & $\mathrm{n}^{*}$ & $\begin{array}{l}\text { Total } \\
\text { Income }\end{array}$ & & & & \\
\hline \multicolumn{9}{|l|}{ Ecotourism } \\
\hline Homestay & 6 & 500000 & 13 & 4140000 & 19 & $13.1 \%$ & 4640000 & $8.5 \%$ \\
\hline Canoeing & 0 & 0 & 5 & 388000 & 5 & $3.4 \%$ & 388000 & $0.7 \%$ \\
\hline Jeep safari & 3 & 740000 & 2 & 56400 & 5 & $3.4 \%$ & 796400 & $1.5 \%$ \\
\hline Elephant safari & 1 & 180000 & 1 & 200000 & 2 & $1.4 \%$ & 380000 & $0.7 \%$ \\
\hline $\begin{array}{l}\text { Tourism employment } \\
\text { (Tourist guide) }\end{array}$ & 2 & 120000 & 0 & 0 & & & 120000 & $0.2 \%$ \\
\hline Ecotourism total & & 1540000 & & 4784400 & & & 6324400 & $11.6 \%$ \\
\hline \multicolumn{9}{|l|}{ Non-ecotourism } \\
\hline Agriculture & 23 & 2790000 & 32 & 2105000 & 55 & $37.9 \%$ & 4895000 & $9.0 \%$ \\
\hline Livestock keeping & 16 & 436000 & 5 & 760000 & 21 & $14.5 \%$ & 1196000 & $2.2 \%$ \\
\hline Trade & 9 & 1634000 & 13 & 5822000 & 22 & $15.2 \%$ & 7456000 & $13.6 \%$ \\
\hline $\begin{array}{l}\text { Employment } \\
\text { (excluding tourism) }\end{array}$ & 3 & 450000 & 12 & 3254000 & 15 & $10.3 \%$ & 3704000 & $6.8 \%$ \\
\hline Remittance & 14 & 5520000 & 29 & 17860000 & 43 & $29.7 \%$ & 23380000 & $42.8 \%$ \\
\hline Wage labor & 26 & 4406000 & 13 & 1968000 & 39 & $26.9 \%$ & 6374000 & $11.7 \%$ \\
\hline Sale of forest product & 7 & 198000 & 21 & 1130000 & 28 & $19.3 \%$ & 1328000 & $2.4 \%$ \\
\hline Non Ecotourism Total & & 15434000 & & 32899000 & & & 48333000 & $88.4 \%$ \\
\hline Total & & & & & & & 54657400 & \\
\hline
\end{tabular}

Source: Field Survey, 2018

Note: (1) "n" indicates the size of an entire sample from each study site, and " $\mathbf{n} *$ " refers to the number of respondents out of "n".

(2) Respondents' were engaged in multiple activities.

\subsection{Income Based on Ethnicity and Landholding Status}

As per Table 4, among the four ethnic groups, Brahman-Kshetri benefited more from agriculture, followed by livestock keeping and remittances. However, they were least involved in ecotourism. In the context of the Tharu community, they were more involved in agriculture, while the Janajati benefited mostly from remittances followed by ecotourism and the sale of forest products. Dalits were more involved in the sale of forest products and wage labor. As per the BZCFs' officials, the Tharu community is actively involved in homestay operations, whereas the Janjati community is employed in ecotourism activities operating inside the BZCFs, such as jeep safaris, canoe trips, and tourist guidance. During the survey, respondents revealed that people who are not residing in Kumroj and Amaltari are engaged in ecotourism activities such as Jeep and elephant safaris, which reduces opportunities for locals to engage in ecotourism.

From a landholding point of view, households with private landholdings were mostly engaged in agriculture followed by ecotourism. They had little involvement in the sale of forest products. The results also indicate that landless communities were marginally involved in ecotourism and relatively more engaged in wage labor and selling of forest products. 
Table 4. Percentage of various sources of income based on ethnicity and landholding status

\begin{tabular}{|c|c|c|c|c|c|c|c|c|}
\hline \multirow{2}{*}{$\begin{array}{l}\text { Variables } \\
\text { Ethnicity }\end{array}$} & \multicolumn{8}{|c|}{ Sources of Income } \\
\hline & Ecotourism & Agriculture & $\begin{array}{c}\text { Livestock } \\
\text { keeping }\end{array}$ & Trade & Employment & Remittance & $\begin{array}{l}\text { Wage } \\
\text { labor }\end{array}$ & $\begin{array}{c}\text { Sale of } \\
\text { forest product }\end{array}$ \\
\hline $\begin{array}{l}\text { Brahman-Kshetri } \\
(32 \mathrm{HH})\end{array}$ & $\begin{array}{c}3 \\
(9 \%)\end{array}$ & $\begin{array}{c}17 \\
(53 \%)\end{array}$ & $\begin{array}{c}12 \\
(38 \%)\end{array}$ & $\begin{array}{c}4 \\
(13 \%)\end{array}$ & $\begin{array}{c}6 \\
(19 \%)\end{array}$ & $\begin{array}{c}9 \\
(28 \%)\end{array}$ & $\begin{array}{c}6 \\
(19 \%)\end{array}$ & 0 \\
\hline $\begin{array}{l}\text { Tharu } \\
\text { (68 HH) }\end{array}$ & $\begin{array}{c}18 \\
(26 \%)\end{array}$ & $\begin{array}{c}26 \\
(38 \%)\end{array}$ & $\begin{array}{c}5 \\
(7 \%)\end{array}$ & $\begin{array}{c}16 \\
(24 \%)\end{array}$ & $\begin{array}{c}7 \\
(10 \%)\end{array}$ & $\begin{array}{c}20 \\
(29 \%)\end{array}$ & $\begin{array}{c}21 \\
(31 \%)\end{array}$ & $\begin{array}{c}7 \\
(10 \%)\end{array}$ \\
\hline $\begin{array}{l}\text { Janajati } \\
(29 \mathrm{HH})\end{array}$ & $\begin{array}{c}10 \\
(34 \%)\end{array}$ & $\begin{array}{c}7 \\
(24 \%)\end{array}$ & $\begin{array}{c}4 \\
(14 \%)\end{array}$ & $\begin{array}{c}2 \\
(7 \%)\end{array}$ & $\begin{array}{c}2 \\
(7 \%)\end{array}$ & $\begin{array}{c}11 \\
(38 \%)\end{array}$ & $\begin{array}{c}4 \\
(14 \%)\end{array}$ & $\begin{array}{c}10 \\
(34 \%)\end{array}$ \\
\hline $\begin{array}{l}\text { Dalit } \\
(16 \mathrm{HH})\end{array}$ & 0 & $\begin{array}{c}5 \\
(31 \%) \\
\end{array}$ & 0 & 0 & 0 & $\begin{array}{c}3 \\
(19 \%) \\
\end{array}$ & $\begin{array}{c}8 \\
(50 \%) \\
\end{array}$ & $\begin{array}{c}11 \\
(69 \%) \\
\end{array}$ \\
\hline \multicolumn{9}{|l|}{$\begin{array}{l}\text { Landholding } \\
\text { status }\end{array}$} \\
\hline $\begin{array}{l}\text { Landless } \\
(33 \mathrm{HH})\end{array}$ & $\begin{array}{c}2 \\
(6 \%)\end{array}$ & $\begin{array}{c}3 \\
(9 \%)\end{array}$ & $\begin{array}{c}2 \\
(6 \%)\end{array}$ & $\begin{array}{c}4 \\
(12 \%)\end{array}$ & $\begin{array}{c}1 \\
(3 \%)\end{array}$ & $\begin{array}{c}10 \\
(30 \%)\end{array}$ & $\begin{array}{c}24 \\
(73 \%)\end{array}$ & $\begin{array}{c}18 \\
(55 \%)\end{array}$ \\
\hline $\begin{array}{l}\text { Private land } \\
(112 \mathrm{HH})\end{array}$ & $\begin{array}{c}29 \\
(26 \%)\end{array}$ & $\begin{array}{c}52 \\
(46 \%)\end{array}$ & $\begin{array}{c}19 \\
(17 \%)\end{array}$ & $\begin{array}{c}18 \\
(16 \%)\end{array}$ & $\begin{array}{c}14 \\
(13 \%)\end{array}$ & $\begin{array}{c}33 \\
(29 \%)\end{array}$ & $\begin{array}{c}15 \\
(13 \%)\end{array}$ & $\begin{array}{c}10 \\
(9 \%)\end{array}$ \\
\hline
\end{tabular}

Source: Field Survey, 2018

Note: (1) The figures in parentheses represent the percentage of respondents.

(2) Respondents' were engaged in multiple activities.

(3) HH indicates respondent's household

\subsection{Respondents' Perceptions of Ecotourism}

Table 5 summarizes respondents' perceptions of ecotourism. The results show that most respondents felt that ecotourism activities have increased the income of BZCFUCs. The perceptions of respondents are consistent with the data received from the BZCFUCs, as presented in Figure 2.

Similarly, a higher number of respondents presented favorable attitudes regarding the contribution of ecotourism to forest conservation. The findings indicate that most respondents consider ecotourism to have contributed significantly toward social development as well. Many respondents also recognized the contribution of ecotourism to increasing employment opportunities. However, a higher number of respondents stated that ecotourism did not increase their household income. Despite this, the majority wished for an increase in ecotourism activities in their area. Overall, most respondents were positive about ecotourism, except for the question as to whether it benefited their household income. 
Table 5. Respondents' perceptions of ecotourism

\begin{tabular}{|c|c|c|c|}
\hline Category & $\begin{array}{c}\text { Kumroj } \\
\mathbf{n}=58 \\
\mathbf{n}(\%) \\
\end{array}$ & $\begin{array}{c}\text { Amaltari } \\
\mathbf{n}=\mathbf{8 7} \\
\mathbf{n}(\%)\end{array}$ & Total n $(\%)$ \\
\hline \multicolumn{4}{|c|}{ Ecotourism has enhanced the income of BZCFUC } \\
\hline Agree & $46(79.3 \%)$ & $68(78.2 \%)$ & $114(78.6 \%)$ \\
\hline Disagree & 0 & 0 & 0 \\
\hline Do not know & $12(20.7 \%)$ & $19(21.8 \%)$ & $31(21.4 \%)$ \\
\hline \multicolumn{4}{|c|}{ Ecotourism has helped with the conservation of the forest } \\
\hline Agree & $42(72.4 \%)$ & $53(60.9 \%)$ & $95(65.6 \%)$ \\
\hline Disagree & 0 & $16(18.4 \%)$ & $16(11.0 \%)$ \\
\hline Do not know & $16(27.6 \%)$ & $18(20.7 \%)$ & $34(23.4 \%)$ \\
\hline \multicolumn{4}{|c|}{ Ecotourism has benefited social development } \\
\hline Agree & $39(67.2 \%)$ & $56(64.4 \%)$ & $95(65.5 \%)$ \\
\hline Disagree & $6(10.3 \%)$ & $30(34.5 \%)$ & $36(24.8 \%)$ \\
\hline Do not know & $13(22.5 \%)$ & $1(1.1 \%)$ & $14(9.7 \%)$ \\
\hline \multicolumn{4}{|c|}{ Thanks to ecotourism, local employment has increased } \\
\hline Agree & $38(65.5 \%)$ & $60(69.0 \%)$ & $98(67.6 \%)$ \\
\hline Disagree & $8(13.8 \%)$ & $26(29.9 \%)$ & $34(23.4 \%)$ \\
\hline Do not know & $12(20.7 \%)$ & $1(1.1 \%)$ & $13(9.0 \%)$ \\
\hline \multicolumn{4}{|c|}{ Ecotourism has helped to increase your household income } \\
\hline Agree & $12(20.7 \%)$ & $19(21.8 \%)$ & $31(21.4 \%)$ \\
\hline Disagree & $39(67.2 \%)$ & $68(78.2 \%)$ & $107(73.8 \%)$ \\
\hline Do not know & $7(12.1 \%)$ & 0 & $7(4.8 \%)$ \\
\hline \multicolumn{4}{|c|}{ You wish ecotourism would increase in your area } \\
\hline Agree & $48(82.8 \%)$ & $80(92.0 \%)$ & $128(88.3 \%)$ \\
\hline Disagree & $10(17.2 \%)$ & $7(8.0 \%)$ & $17(11.7 \%)$ \\
\hline Do not know & 0 & 0 & 0 \\
\hline
\end{tabular}

Source: Field Survey, 2018

Note: 1) The figures in parentheses represent the percentage of respondents.

2) " $\mathbf{n}$ indicates the size of an entire sample from each study site.

\section{Discussion}

The study revealed that BZCFUCs were generating a significant amount of revenue from ecotourism activities. This finding is further supported by this study's results on respondents' perceptions of ecotourism. Based on perception analysis and field observations, we were able to understand the reality of ecotourism with more depth. Although ecotourism has increased the revenue of community forestry, this trend appears less positive when the respondents' household dependency ratio on ecotourism is considered. This study shows that income from ecotourism is not distributed evenly among the households of different ethnic groups. Similarly, not all communities of different economic statuses enjoyed equitable employment opportunities in ecotourism. Some communities lacked opportunities to engage in ecotourism activities, more broadly, and are not able to conduct homestay operations, in particular. As such, the purpose of introducing ecotourism has not been achieved, as the primary goal of ecotourism initiatives is to reduce poverty and forest dependency. Many indigenous people surveyed in this study remained disadvantaged and continued to be squatters. Moreover, ethnic groups that owned private lands were able to participate in eco-tourism activities such as homestay operations, thereby realizing the positive effects of ecotourism. In contrast, landless households and households that were solely 
dependent on forest resources as a source of income experienced negative effects of the industry more acutely. Since they did not have land and did not enjoy other employment opportunities, they lost their only source of income, which was the sale of forest products. Our study found that Dalit households were neither involved in ecotourism nor had any employment opportunities. In contrast, ethnic communities such as Brahman-Kshetri, who were marginally involved in ecotourism, were slightly affected after their second highest source of income, that is, livestock grazing, was affected by the introduction of stringent ecotourism rules. This finding is consistent with (Gurung et al., 2009). Our study also revealed that the Tharu community benefitted the most from ecotourism activities among all the other ethnic groups residing in the selected hamlet and a similar pattern can be observed among respondents with private land holdings. This finding is consistent with Nyaupane and Thapa's (2004) observation that lodge owners in the Annapurna Sanctuary Trail area were the only residents who benefited from tourism. A similar result was shown in a study by Nepal (2002): among the respondents, homestay operators benefited from ecotourism. This result is consistent with a previous study conducted in the PAs of Nepal by Acharya and Halpenny (2013).

The disadvantaged groups in the community could not assert themselves and claim equal benefits from ecotourism interventions. This type of gap could increase in the near future and lead to greater inequality within the community, which could trigger social friction and disharmony and coerce people to break forest rules, thereby disrupting ecotourism objectives. This is consistent with Thakali's (1995) work in which, due to unequal earnings, a disharmonious scenario was observed in the Annapurna Conservation Area. Therefore, BZCF representatives, PA officials, and stakeholders must work toward equally benefiting every class and community.

Both of the villages that were examined in this study have formed a homestay operating committee to facilitate homestay operations in their area. The collected revenue was invested in sustainable development activities, including road construction, economic programs, and the preservation of the local culture as well as education and health services. The residents were encouraged to use the generated revenue to facilitate conservation activities and arrange other social interventions such as community clinics, fish farms, and cultural shows. Notably, our study shows that homestay operators who have benefited from ecotourism, particularly from Amaltari, were heavily dependent on forests in the past. Recently, they seem to have reduced their dependence on forests because they are focusing on homestay operations. Thus, it can be inferred that homestays also contribute toward reducing local households' dependency on forests. In the case of Kumroj, they have not yet been able to collect adequate revenue to invest in social purposes. Indeed, Kumroj almost failed to achieve its target of attracting more tourists to its homestays. However, based on informal interviews with locals, we found that the village is facing strong competition from Sauraha, a popular tourist destination just $3 \mathrm{~km}$ away. Given such a case, homestays should not have been established in this area. Therefore, it can be stated that government agencies and non-governmental organizations involved in establishing homestays in Kumroj failed in their estimation. Therefore, without understanding the cause of success, it may be a misconception that homestays would be as successful in Kumroj as in Amaltari. Hence, we must learn from the past and improve the viability of homestays in Kumroj with support from both the government and non-governmental organizations. Ezebilo, Mattsson, and Afolami (2010) opined that if local people feel that they would not benefit, they may not cooperate with any projects launched in the PAs. In our study sites, households from the squatter group were mostly deprived of the benefits generated from ecotourism activities, including homestays. They resorted to trading forest products illegally as a livelihood alternative, which ultimately poses challenges for BZ conservation. Therefore, it is crucial to establish economic interventions for communities that are deprived of the benefits of ecotourism.

\section{Conclusion}

This study is unique in that it evaluated the impact of ecotourism activities on multiple ethnic groups and households of different economic statuses, thereby revealing a more comprehensive picture of the current situation. Based on our study, it is concluded that the introduction of eco-tourism has positive and negative effects on various ethnic communities and households categorized into different economic classes. Communities engaged in multiple activities such as agriculture and remittances were affected the least, while ethnicities solely engaged in the sale of forest products and wage labor were affected the most. This shaped the perception of various ethnic groups toward ecotourism and conservation practices. The beneficiaries deem eco-tourism a positive change and wish to increase ecotourism activities in their areas, as ecotourism is still not considered a major source of household income. Despite ecotourism's negative impacts, many community members - especially those engaged in wage labor and the sale of forest products - still wish to be part of eco-tourism activities. The deeper point here is that the information and findings from this study can help policy makers develop an overall understanding that accounts for all stakeholders' perspectives, that is, the perspectives 
of those who own land, those who are engaged in ecotourism, and those who are landless and have experienced little benefit from ecotourism - put differently, this information can help policy makers design policies with minimal bias and that equitably distribute the benefits of ecotourism. Important to note here is that we found that the education level in both villages is low; therefore, educating the locals is an important tool to help to develop their skillset and also increase their participation both directly and indirectly. We also found that some of the locals resented their lack of opportunity to participate in certain ecotourism activities such as safaris because the majority of these are conducted by those who are not part of the local community. To allow local communities to experience economic benefits derived from ecotourism, policymakers need to strike the right balance with effective inclusion of local communities. In the study, communities were divided into two categories based on their landholding status. We recommend that those who own land should engage in agriculture and other activities, while those who do not own any land should be given priority to engage in activities such as Jeep and elephant safaris so that they can participate in ecotourism and realize the benefits as well. As it stands, there is an immediate need to make current activities more participatory and community-oriented in order to provide benefits to disadvantaged groups who are still struggling to be a part of mainstream ecotourism and have yet to experience any of its benefits. Hence, when considering these aspects, policymakers must rethink and reframe policies in such a way so that they protect the interests of people of low economic status and those at a disadvantage because they do not own the land or have the facilities needed to conduct ecotourism activities.

\section{Acknowledgments}

This work was supported by the Grant-in-Aid for Scientific Research received from the Japanese Government and the Toyoaki Foundation in Japan. We gratefully acknowledge Dr. Minoru Kondo, stakeholders of Chitwan National Park, the Buffer Zone Committee Forest User Groups, and the homestay operating committees for their kind assistance with our field survey. We wish to thank all the interviewees for their kindness and cooperation in providing information.

\section{References}

Acharya, B. P., \& Halpenny, E. A. (2013). Homestays as an alternative tourism product for sustainable community development: A case study of women-managed tourism product in rural Nepal. Tourism Planning and Development, 10(4), 367-387. https://doi.org/10.1080/21568316.2013.779313

Bhandari, D., \& Jianhua, Z. (2017). Household dependency on buffer zone community forest and its implication for management of Chitwan National Park, Nepal. International Journal of Sciences, 3(03), 68-80. https://doi.org/10.18483/ijsci.1214

Bhatt, D. P., \& Dhakal, T. N. (2018). Effectiveness of ecotourism: A case of Chitwan National Park. Journal of Advanced Academic Research, 4(1), 136-141. https://doi.org/10.3126/jaar.v4i1.19527

Bhattarai, B. R., Wright, W., Poudel, B. S., Aryal, A., Yadav, B. P., \& Wagle, R. (2017). Shifting paradigms for Nepal's protected areas: History, challenges and relationships. Journal of Mountain Science, 14(5), 964-979. https://doi.org/10.1007/s11629-016-3980-9

Bhusal, N. P. (2009). Chitwan National Park: A prime destination of eco-tourism in Central Tarai Region, Nepal. The Third Pole, 5, 70-75. https://doi.org/10.3126/ttp.v5i0.1956

Bhusal, N. P. (2014). Buffer zone management system in protected areas of Nepal. The Third Pole: Journal of Geography Education, 11-12, 34-44. https://doi.org/10.3126/ttp.v11i0.11558

Chitwan National Park (CNP). (2016). Grassland habitat mapping in Chitwan National Park. Chitwan, Nepal: Chitwan National Park Office. Retrieved https://www.chitwannationalpark.gov.np/index.php/document-repository/publications-chitwan-national-par k/39-grassland-habitat-mapping-cnp-printed/file

CNP. (2017). Chitwan National Park and buffer zone tourism plan 2017-2022. Chitwan, Nepal: Retrieved from Chitwan National Park Office. Retrieved from https://www.chitwannationalpark.gov.np/index.php/document-repository/publications-chitwan-national-par k/49-chitwan-tourism-plan-final-2074/file

CNP. (2018a). Chitwan National Park annual report 2017/18. Chitwan, Nepal: Retrieved from Chitwan National Park Office. Retrieved from https://www.chitwannationalpark.gov.np/index.php/document-repository/publications-chitwan-national-par k/51-annual-report-074-075/file

CNP. (2018b). Management plan of chitwan national park and buffer zone (2018-2022). Chitwan, Nepal: 
$\begin{array}{lllll}\text { Chitwan National Park } & \text { Office. } & \text { Retrieved }\end{array}$ https://drive.google.com/file/d/1wh2gV0eKxGT3vC-7JMgQuVBthEm-PIO1/view

Department of National Parks and Wildlife Conservation. (2018). Protected areas of Nepal (in Nepali). Kathmandu, Nepal: Department of National Parks and Wildlife Conservation Office. Retrieved from http://www.dnpwc.gov.np/media/publication/Protected_Area_of_Nepal-2075.pdf

Dhakal, B., \& Thapa, B. (2015). Buffer zone management issues in Chitwan National Park, Nepal: A case study of Kolhuwa Village Development Committee. Parks, 21(2), 63-73. https://doi.org/10.2305/iucn.ch.2014.parks-21-2bd.en

Doan, T. M. (2000). The effects of ecotourism in developing nations: An analysis of case studies. Journal of Sustainable Tourism, 8(4), 288-304. https://doi.org/10.1080/09669580008667365

Dongol, P. (2013). Impact of tourism in the local economy of Sauraha. Nepal Tourism and Development Review, 2(1), 148-154. https://doi.org/10.3126/ntdr.v2i1.7384

Ezebilo, E. E., Mattsson, L., \& Afolami, C. A. (2010). Economic value of ecotourism to local communities in the Nigerian Rainforest Zone. Journal of Sustainable Development, 3(1), 51-60. https://doi.org/10.5539/jsd.v3n1p51

Government of Nepal. (1999). Buffer zone management guideline, 1999. Kathmandu, Nepal: Ministry of Forest ad Soil Conservation. Retrieved from http://nepalpolicynet.com/images/documents/forest/regulation/1999_MoFSC_Buffer Zone Management Guideline.pdf

Gurung, B., Nelson, K. C., \& Smith, J. L. D. (2009). Impact of grazing restrictions on livestock composition and husbandry practices in Madi Valley, Chitwan National Park, Nepal. Environmental Conservation, 36(4), 338-347. https://doi.org/10.1017/S0376892910000160

International Union for Conservation of Nature. (2018). Chitwan National Park 2017 conservation outlook assessment. Gland, Swizerland. Retrieved from https://worldheritageoutlook.iucn.org/node/1011

Jamal, S. A., Othman, N., \& Muhammad, N. M. N. (2011). Tourist perceived value in a community-based homestay visit: An investigation into the functional and experiential aspect of value. Journal of Vacation Marketing, 17(1), 5-15. https://doi.org/10.1177/1356766710391130

K.C., A. (2016). Ecotourism and its role in sustainable development of Nepal. In L. Butowski (Ed.), Tourism From empirical research towards practical application (pp. 32-59). London: IntechOpen. https://doi.org/http://dx.doi.org/10.5772/62308

Kandel, S., Harada, K., Adhikari, S., Dahal, N. K., \& Dhakal, M. (2020). Local perceptions of forest rules and interactions between rules, ecotourism, and human-wildlife conflicts: Evidence from Chitwan National Park, Nepal. Tropics, 29(1), 25-39. https://doi.org/10.3759/tropics.ms19-07

Kiper, T. (2013). Role of ecotourism in sustainable development. In M. Ozyavuz (Ed.), Advances in Landscape Architecture (pp. 773-802). London: IntechOpen. https://doi.org/http://dx.doi.org/10.5772/55749

Lamichhane, B. R., Persoon, G. A., Leirs, H., Poudel, S., Subedi, N., Pokheral, C. P., Bhattarai, S., Thapaliya, B. P., \& de Iongh, H. H. (2018). Spatio-temporal patterns of attacks on human and economic losses from wildlife in Chitwan National Park, Nepal. PLoS ONE, 13(4), 1-18. https://doi.org/10.1371/journal.pone.0195373

Lipton, J. K. (2014). Park establishment, tourism, and livelihood changes: A case study of the establishment of Chitwan National Park and the Tharu people of Nepal. American International Journal of Social Science, $3(1), 12-24$.

Lynch, P. A. (2005). The commercial home enterprise and host: A United Kingdom perspective. International Journal of Hospitality Management, 24(4), 533-553. https://doi.org/10.1016/j.jihm.2004.11.001

Ministry of Culture Tourism and Civil Aviation. (2018). Nepal tourism statistics 2017.Kathmandu, Nepal: Retrieved from https://www.tourism.gov.np//files/statistics/11.pdf

Nepal, S. K. (2002). Tourism as a key to sustainable mountain development: The Nepalese Himalayas in $\begin{array}{lllll}\text { retrospect. } & \text { Unasylva, } & \text { 53(208), } & \text { Retrieved } & \text { from }\end{array}$ http://www.fao.org/tempref/docrep/fao/004/y3549e/y3549e03.pdf

Nyaupane, G. P., \& Thapa, B. (2004). Evaluation of ecotourism: A comparative assessment in the Annapurna 
conservation area project, Nepal. Journal of Ecotourism, 3(1), 20-45. https://doi.org/10.1080/14724040408668148

Oli, B. N., \& Dhakal, M. (2018). Policy and institutional reform to biodiversity conservation in Nepal. In M. Dhakal, D. Lamichhane, M. D. Ghimire, A. Poudyal, Y. Uprety, T. Svich, \& M. Pandey (Eds.), 25 years of achievements on biodiversity conservation in Nepal (p. 115). Kathmandu, Nepal: Ministry of Forests and Environment. Retrieved from http://mofe.gov.np/downloadfile/25 Years of Achievements on Biodiversity Conservation In Nepal_1530603709.pdf

Pokharel, R., Poudel, J., Adhikari, R. K., \& Sharma, A. R. (2018). Demand and supply of forest products in Bandevi buffer zone community forest, Chitwan National Park, Nepal. Sustainability in Environment, 3(4), 305. https://doi.org/10.22158/se.v3n4p305

Prabin, G. (2015). Ecoturism as feasible development model, minimum impacts, maximus experience. Case Sauraha and Chitwan National Park (Bachelor's Thesis). Centria University of Applied Sciences, Kokkola, Finland.

Robinson, E. J. Z. (2004). Land encroachment: India's disappearing common lands. (CSAE Working Paper Series 2004-28). Retrieved from https://ideas.repec.org/p/csa/wpaper/2004-28.html

Scheyvens, R. (2000). Promoting women's empowerment through involvement in ecotourism: Experiences from the third world. Journal of Sustainable Tourism, 8(March), 232-249. https://doi.org/10.1080/09669580008667360

Sharma, U. R. (2012). Policy advances in biodiversity conservation in Nepal. In K. P. Acharya \& M. Dhakal (Eds.), Biodiversity conservation in Nepal a success story ( pp. 11-20). Department of National Parks and Wildlife Conservation.

Thakali, S. (1995). Tourism for local community development in mountain areas: Perspectives, issues and guidelines. In P. Sharma (Ed.), Proceedings of the Hindu Kush-Himalayan Regional Workshop on Mountain Tourism for Local Community Development, (pp. 46-53). Kathmandu, Nepal: ICIMOD. Retrieved from http://lib.icimod.org/record/22811

Thakuri, I.B.M., \& Nepal, G. (2018). Community oriented-rural tourism development model. American Economic \& Social Review, 2(1), 1-5. https://doi.org/10.46281/aesr.v2i1.149

Thapa, K. (2012). Ecotourism for (nature) conservation and development. Tigerpaper, 39(3), 4-7.

The International Ecotourism Society. (2015). The definition (online). Available: https://ecotourism.org/what-is-ecotourism/

Thing, S. J., \& Poudel, B. S. (2017). Buffer zone community forestry in Nepal: Examining tenure and management outcomes. Journal of Forest and Livelihood, 15(1), 57-70.

Wall, G. (1997). FORUM Is ecotourism sustainable? Ethnologia Scandinavica, 21(4), $483-491$. https://doi.org/10.1007/s002679900044

Weber, M. (1978). Economy and society: An outline of interpretative sociology (Vol. 1). Berkeley and Los Angeles: University of California Press.

Wells, M., Brandon, K., \& Hannah, L. (1992). People and parks: Linking protected area management with local communitird. Washington, D. C.: The World Bank. Retrieved from http://documents.worldbank.org/curated/en/171421468739524360/People-and-parks-linking-protected-area -management-with-local-communities

Wells, M. P., \& Sharma, U. R. (1998). Socio-economic and political aspects of biodiversity conservation in Nepal. International Journal of Social Economics, 25(2/3/4), $226-243$. https://doi.org/10.1108/03068299810193416

Wight, P. (1995). Sustainable ecotourism balancing economic, environmental and social goals within an ethical framework. Tourism Recreation Research, 20(1), 5-13. https://doi.org/10.1080/02508281.1995.11014727

\section{Note}

Note 1. According to the World Parks Congress, buffer zones are the "areas adjacent to protected areas, on which land is partially restricted to give an added layer of protection area itself while providing valued benefits to neighboring rural communities" (Wells, Brandon, \& Hannah, 1992). Buffer zones can be human settlements, 
agricultural lands, and forested lands, along with rivers and lakes (Bhattarai et al., 2017).

\section{Copyrights}

Copyright for this article is retained by the author(s), with first publication rights granted to the journal.

This is an open-access article distributed under the terms and conditions of the Creative Commons Attribution license (http://creativecommons.org/licenses/by/4.0/). 